\title{
Genetic targets for cancer control are a reality
}

\author{
Paul H. Sugarbaker ${ }^{1}$, Kurt Van der Speeten ${ }^{2}$ \\ ${ }^{1}$ MedStar Washington Hospital Center, Washington, DC, USA; ${ }^{2}$ Department of Surgery, Hospital Oost-Limburg, Genk, Belgium \\ Correspondence to: Paul H. Sugarbaker, MD. MedStar Washington Hospital Center, Washington, DC, USA. Email: Paul.Sugarbaker@outlook.com; \\ Kurt Van der Speeten. Department of Surgery, Hospital Oost-Limburg, Genk, Belgium. Email: Kurt.Vanderspeeten@zol.be. \\ Comment on: Lund-Andersen C, Torgunrud A, Fleten KG, et al. Omics analyses in peritoneal metastasis-utility in the management of peritoneal \\ metastases from colorectal cancer and pseudomyxoma peritonei: a narrative review. J Gastrointest Oncol 2021;12:S191-203.
}

Submitted Dec 16, 2020. Accepted for publication Mar 16, 2021.

doi: 10.21037/jgo-2020-18

View this article at: http://dx.doi.org/10.21037/jgo-2020-18

Lund-Andersen and coworkers from Oslo provide the reader with a review of genomic data (proteomic, transcriptomic...) of PM from colorectal and appendiceal cancer (1). Their goal at this point is to provide the clinician with predictive biomarkers to define the prognosis of peritoneal metastases patients. Also, to identify targets within that cancer cell that will guide the use of multiple treatment options currently available. To administer the correct drug expecting a benefit in a high percentage of patients requires an understanding of the molecular composition of the PM. Tumor biology is the ultimate determinant of outcome in oncology. As such genomic analysis of that tumor biology is bound to become the main indicator for treatment choice (surgical indication, choice of chemotherapy agent...) and predictor of outcome. The authors conclude that the technologies that utilize genomics (DNA information) and transcriptomics (RNA information) are standardized and generally available. Now the challenge is to correlate the omics information with clinical data, including follow-up to determine the utility of the molecular information for patient care.

\section{Acknowledgments}

Funding: None.

\section{Footnote}

Provenance and Peer Review: This article was commissioned by the editorial office, Fournal of Gastrointestinal Oncology for the focused issue "Intraperitoneal Chemotherapy for Peritoneal Metastases: HIPEC, EPIC, NIPEC, PIPAC and More". The article did not undergo external peer review.

Conflicts of Interest: Both authors have completed the ICMJE uniform disclosure form (available at http:// dx.doi.org/10.21037/jgo-2020-18). The focused issue was sponsored by the Peritoneal Surface Oncology Group International (PSOGI). Drs. PHS and KVDS served as the unpaid Guest Editors of the focused issue. The authors have no other conflicts of interest to declare.

Ethical Statement: The authors are accountable for all aspects of the work in ensuring that questions related to the accuracy or integrity of any part of the work are appropriately investigated and resolved.

Open Access Statement: This is an Open Access article distributed in accordance with the Creative Commons Attribution-NonCommercial-NoDerivs 4.0 International License (CC BY-NC-ND 4.0), which permits the noncommercial replication and distribution of the article with the strict proviso that no changes or edits are made and the original work is properly cited (including links to both the formal publication through the relevant DOI and the license). See: https://creativecommons.org/licenses/by-nc$\mathrm{nd} / 4.0 /$. 


\section{References}

1. Lund-Andersen C, Torgunrud A, Fleten KG, et al. Omics analyses in peritoneal metastasis-utility in the

management of peritoneal metastases from colorectal cancer and pseudomyxoma peritonei: a narrative review. J Gastrointest Oncol 2021;12:S191-203.

Cite this article as: Sugarbaker PH, Van der Speeten K. Genetic targets for cancer control are a reality. J Gastrointest Oncol 2021;12(Suppl 1):S204-S205. doi: 10.21037/jgo-2020-18 